\title{
AIDS and Behavior \\ VALIDATION OF THE AIDS PREVENTION QUESTIONNAIRE: A BRIEF SELF- REPORT INSTRUMENT TO ASSESS RISK OF HIV INFECTION AND GUIDE BEHAVIORAL CHANGE \\ --Manuscript Draft--
}

\begin{tabular}{|c|c|c|}
\hline Manuscript Number: & \multicolumn{2}{|l|}{ AIBE-D-18-00110R2 } \\
\hline Full Title: & \multicolumn{2}{|c|}{$\begin{array}{l}\text { VALIDATION OF THE AIDS PREVENTION QUESTIONNAIRE: A BRIEF SELF- } \\
\text { REPORT INSTRUMENT TO ASSESS RISK OF HIV INFECTION AND GUIDE } \\
\text { BEHAVIORAL CHANGE }\end{array}$} \\
\hline Article Type: & \multicolumn{2}{|l|}{ Original Research } \\
\hline Keywords: & \multicolumn{2}{|c|}{$\begin{array}{l}\text { HIV prevention; sexual risk behavior; level of risk; psychometric properties; } \\
\text { preventive interventions }\end{array}$} \\
\hline Corresponding Author: & \multicolumn{2}{|c|}{$\begin{array}{l}\text { Rafael Ballester-Arnal, Ph.D. } \\
\text { Facultad de Ciencias de la Salud. Universitat Jaume I de Castelló } \\
\text { Castellón, SPAIN }\end{array}$} \\
\hline \multicolumn{3}{|l|}{$\begin{array}{l}\text { Corresponding Author Secondary } \\
\text { Information: }\end{array}$} \\
\hline Corresponding Author's Institution: & \multicolumn{2}{|c|}{ Facultad de Ciencias de la Salud. Universitat Jaume I de Castelló } \\
\hline \multicolumn{3}{|l|}{$\begin{array}{l}\text { Corresponding Author's Secondary } \\
\text { Institution: }\end{array}$} \\
\hline First Author: & \multicolumn{2}{|l|}{ María Dolores Gil-Llario } \\
\hline \multicolumn{3}{|l|}{ First Author Secondary Information: } \\
\hline \multirow[t]{5}{*}{ Order of Authors: } & \multicolumn{2}{|l|}{ María Dolores Gil-Llario } \\
\hline & \multicolumn{2}{|l|}{ Estefanía Ruiz-Palomino, Ph. D. } \\
\hline & \multicolumn{2}{|l|}{ Vicente Morell-Mengual } \\
\hline & \multicolumn{2}{|l|}{ Cristina Giménez-García } \\
\hline & \multicolumn{2}{|l|}{ Rafael Ballester-Arnal } \\
\hline \multicolumn{3}{|c|}{ Order of Authors Secondary Information: } \\
\hline \multirow[t]{2}{*}{ Funding Information: } & $\begin{array}{l}\text { Universidad Jaume I-Fundación Bancaixa } \\
\text { (P1 1B2006-19) }\end{array}$ & Ph. D. Rafael Ballester-Arnal \\
\hline & $\begin{array}{l}\text { Fundación para la Investigación y la } \\
\text { Prevención del Sida en España } \\
\text { (exp. 36639/07) }\end{array}$ & Ph. D. Rafael Ballester-Arnal \\
\hline Abstract: & \multicolumn{2}{|c|}{$\begin{array}{l}\text { This paper describes the process of building and validating the AIDS Prevention } \\
\text { Questionnaire (CPS), a brief HIV risk assessment measure. An initial } 64 \text {-items bank } \\
\text { was filled out by } 466 \text { young people ( } 192 \text { men and } 274 \text { women), aged between } 17 \text { to } 26 \\
\text { years }(\mathrm{M}=20.62 ; \mathrm{SD}=2.15) \text {. The exploratory factor analysis revealed five } \\
\text { components: Knowledge about HIV, Condom Attitudes, Intentions of Condom Use, } \\
\text { Safe sexual behavior and Stigma and discrimination towards people living with HIV. } \\
\text { This structure was confirmed by confirmatory factor analysis. The internal consistency } \\
\text { for the different components ranged from } 67 \text { to } .74 \text {. Moreover, CPS has a } \\
\text { classification system that allows determining the level of risk. These results support the } \\
\text { AIDS Prevention Questionnaire as a valid and reliable measure to detect earlier the } \\
\text { risk for HIV infection and to design adjusted preventive interventions }\end{array}$} \\
\hline Response to Reviewers: & \multicolumn{2}{|c|}{$\begin{array}{l}\text { We would like to express our appreciation by reviewers' suggetions and comments. } \\
\text { We have followed all the recommendations for improvement the manuscript sending. }\end{array}$} \\
\hline
\end{tabular}


Title: Validation of the AIDS Prevention Questionnaire: a brief self-report instrument to assess risk of HIV infection and guide behavioral change

Suggested running head: Validation of the Aids Prevention Questionnaire

Gil-Llario M.D. ${ }^{1}$, Ruiz-Palomino, E. ${ }^{2}$, Morell-Mengual, V. ${ }^{1}$, Giménez-García, C. ${ }^{2}$, and Ballester-Arnal, R. ${ }^{2}$

\footnotetext{
${ }^{1}$ Department of Developmental and Educational Psychology Universitat de València Av. Blasco Ibáñez, 21 46010 Valencia (Spain) ${ }^{2}$ Department of Clinical and Basic Psychology and Psychobiology Universitat Jaume I of Castellón Avda. Vicent Sos Baynat s/n 12071 Castellón de la Plana (Spain)

E-mail: rballest@uji.es

Phone: +34 964729726
} 


\section{Compliance with Ethical Standards:}

Funding - This work was supported by Universidad Jaume I-Fundación Bancaixa (P1 1B2006-19) and by the Spanish Foundation for AIDS Research and Prevention known as Fundación para la Investigación y la Prevención del Sida en España (exp. 36639/07).

Conflict of interest - The authors declare no competing interests.

Ethical approval - All procedures performed in studies involving human participants were in accordance with the ethical standards of the institutional and/or national research committee and with the 1964 Helsinki declaration and its later amendments or comparable ethical standards.

Informed consent - Informed consent was obtained from all individual participants included in the study. 
VALIDATION OF THE AIDS PREVENTION QUESTIONNAIRE: A BRIEF

1

SELF-REPORT INSTRUMENT TO ASSESS RISK OF HIV INFECTION AND GUIDE BEHAVIORAL CHANGE 


\section{Resumen}

Este artículo describe el proceso de construcción y validación del Cuestionario para la Prevención del Sida (CPS), un instrumento breve de evaluación del riesgo de infección por VIH. Un banco inicial de 64 ítems fue cumplimentado por 466 jóvenes (192 hombres y 274 mujeres), con edades comprendidas entre 17 y 26 años $(M=20.62 ; D T=$ 2.15). El análisis factorial exploratorio reveló cinco componentes: información y conocimientos sobre VIH, autoeficacia percibida en el uso del preservativo, intención de uso del preservativo, uso autoinformado del preservativo y solidaridad y empatía hacia las personas que viven con VIH. Esta estructura fue ratificada mediante análisis factorial confirmatorio. La consistencia interna para los distintos componentes osciló entre .67 y .74 . Además, el CPS presenta un sistema de clasificación que permite determinar el nivel de riesgo. Estos resultados indican que el Cuestionario para la Prevención del Sida es un instrumento válido y fiable para la detección temprana del nivel de riesgo para la infección por VIH y para el diseño de intervenciones preventivas personalizadas.

Palabras clave: prevención del VIH, conducta sexual de riesgo, nivel de riesgo, propiedades psicométricas, intervenciones preventivas 
Abstract

This paper describes the process of building and validating the AIDS Prevention Questionnaire (CPS), a brief HIV risk assessment measure. An initial 64-items bank was filled out by 466 young people (192 men and 274 women), aged between 17 to 26 years $(M=20.62 ; S D=2.15)$. The exploratory factor analysis revealed five components: Knowledge about HIV, Condom Attitudes, Intentions of Condom Use, Safe sexual behavior and Stigma and discrimination towards people living with HIV. This structure was confirmed by confirmatory factor analysis. The internal consistency for the different components ranged from .67 to .74. Moreover, CPS has a classification system that allows determining the level of risk. These results support the AIDS Prevention Questionnaire as a valid and reliable measure to detect earlier the risk for HIV infection and to design adjusted preventive interventions.

Keywords: HIV prevention, sexual risk behavior, level of risk, psychometric properties, preventive interventions 


\section{Introduction}

HIV/AIDS remains one of the most serious global health problems. At this moment, global rate of new HIV diagnoses in Spain is 7.2 per 100,000 population [1]. The information system for new HIV diagnoses (SINIVIH) reported 3,353 new HIV diagnoses last year, as well as 86.663 people living with HIV in Spain. New HIV diagnoses are mainly related to sexual transmission. In particular, transmission in men who have sex with men (MSM) was the most frequent route of infection $(53.1 \%)$, followed by heterosexual transmission, which represented $26.5 \%$, and injecting drug users (IDU), who made up 3.6\%. Men represented $83.9 \%$ of new HIV diagnoses in 2016 and the mean rates for men and women were 12.3 and 2.2 per 100,000 population. Young people under 30 years account for $25.8 \%$ of new infections. Furthermore, $46 \%$ showed signs of delayed diagnosis (with less than 350 CD-4 cells), even though HIV testing is available, confidential and free of charge for everybody [2].

Nowadays, surveillance on AIDS cases shows that epidemic is based primarily on risky sexual behaviors. Different behavioral change theories have developed a conceptual framework for HIV prevention. The Health Belief Model (HBM) [3], the Theory of Reasoned Action (TRA) [4] or Planned Behavior (TPB) [5], the InformationMotivation-Behavioral Skills Model (IMB) [6], and the Social Cognitive Theory (SCT) [7], have been the most relevant in this field of knowledge. Each of them has identified a number of constructs that would be predictors of sexual risk behavior [8].

In these decades, multiple scales and questionnaires have been published in different countries that evaluate the main components of these models (see Table 1): beliefs and attitudes (for example: Multidimensional Condom Attitudes Scale [9]; HIVAntibody Testing Attitude Scale [10]; HIV/AIDS Attitudes Scale [11]; HIV/AIDS Stigma Scale [12]; Condom Use Expectancy Scale [13]; Condom Barriers and 
Motivations Scale [14], HIV Attitudes Scale [15]), knowledge and information (for example: HIV Knowledge Questionnaire [16]; HIV and other STI Knowledge Scale [17]), self-efficacy (for example: Condom Use Self-Efficacy Scale [18]; Specific Condom Use Self-efficacy [19]; Modified Condom Outcome Expectancy Scale [20]; Condom Use Self-efficacy Measure [21]), perception of risk (for example: Fear of AIDS Instrument [22]; Risk-Taking Questionnaire [23]; Perceived Risk of HIV Scale [24]; Multicomponent AIDS Phobia Scale [25], Worry about Sexual Outcomes [26]); or behavior and behavioral intention (for example: The Safe Sex Behavior Questionnaire [27]; Condom Influence Strategy Questionnaire [28]; HIV Risk Behavior Questionnaire [29]; HIV-Risk Index [30]).

Others questionnaires have been based on some models: HBM (AIDS Health Belief Scale) [31]), IMB (ES 5 Questionnaire) [32]) or TPB (Sexual Risk Behavior Scale [33]). The others measure a series of constructs related to different theoretical approaches [34-41]. All of them have adequate psychometric properties, are usually written in English, the number of items range from 30 to 170 and include three to seven components.

There are some unidimensional scales mentioned above in the Spanish context $[15,17,25,26]$. The adaptation of the HIV/AIDS-164 Scale [37] by Bermúdez et al. [42], is composed of factual knowledge, misconceptions, attitudes, perceived susceptibility, and self-efficacy. The HIV-Risk Index by Ballester-Arnal et al. [30] estimates HIV risk exposure among young people through a global score based on direct and indirect indicators.

After reviewing literature (see Table 1), we have not found a brief multidimensional assessment measure in which all theoretical perspectives are integrated, broader vision of risk behavior for HIV infection is provided (knowledge, 
attitudes towards HIV and safe sex, self-efficacy, behavioral intention, preventive behavior and stigma towards people living with HIV), and health care professionals were supported to make a more extensive use, for example to make decisions about specifics interventions actions. The AIDS Prevention Questionnaire (CPS) has two purposes: firstly, the diagnosis of risk profile for HIV infection, and secondly, the design, planning and evaluation of the effectiveness of preventive interventions to change sexual risk behavior. CPS integrates quantitative and qualitative assessment methods. In the present study, the construction and validation of a descriptive and explanatory measure of risk behavior for HIV/AIDS addressed to adolescents and young Hispanics is presented.

\section{INSERT TABLE 1}

\section{Method}

\section{Participants}

Four hundred and sixty-six Spanish young people were assessed (58.8\% were women and $41.2 \%$ were men) in different activities organized by XXX. The age ranged between 17 and 26 years $\left(M_{\text {age }}=20.62 ; S D=2.15\right)$. Most of them self-identified as heterosexual (females: 93\%; males: 88\%) and some of them as homosexual (females: 2\%; males: $9 \%$ ) or bisexual (females: 5\%; males: 3\%). Regarding country of origin, $98 \%$ were Spanish and $2 \%$ were from other countries. Concerning sexual experience, $89.9 \%$ of participants reported mutual masturbation, followed by vaginal sex $(88.8 \%)$, oral sex $(87.1 \%)$ and anal sex $(30.5 \%)$.

\section{Measures}

AIDS Prevention Questionnaire (Cuestionario de Prevención del Sida or CPS) is a self-administered measure that includes 44 different response format questions: 14 dichotomous items, 2 multiple choice items, 24 Likert-type items and 4 continuous 0 to 
100 items. The questionnaire considers HIV/AIDS prevention as a multidimensional perspective and uses the sociocognitive models of health behavior as theoretical reference. The main components are information and knowledge about HIV (12 items), attitudes and perceived self-efficacy (14 items), behavioral intention condom use (6 items), self-reported use of condom and HIV antibody testing (7 items), and solidarity and empathy towards people living with HIV (5 items).

Description of the CPS domains:

1. Knowledge about HIV (K-HIV). A series of statements about the level of perceived information (items 1, 2 and 10), real knowledge about routes of transmission and risky practices (items 7 and 8), types of information sources (item 3), preventive measures (item 9), HIV antibody testing (items 11 and 12), and the impact of disease in people living with HIV (items 4, 5 and 6).

2. Self-efficacy and attitudes (SEA). A series of statements that describe ability and skills to use condoms such as buying, putting or refusing unsafe sexual intercourse (item 13, 18, 20 and 21), and feelings related to sexual communication (item 14, 15 and 16), influence of drugs and sexual excitation on the use of condoms (item 17 and 19). Moreover, some items ask about perceived probability and fear of disease and perceived severity (item 22, 23 and 24), subjective norm (item 26) and trust on condoms (item 25) are included.

3. Condom use intention (CUSEI). A series of statements that measure behavioral intention of condom use in different sexual practices (item 27, 28 and 29), types of partner (item 30 and 31) and risk scenarios (item 32).

4. Safe sexual behavior (SAS-B). A series of self-reported statements about frequency of condom use in different sexual practices (item 33, 34 and 35), types of partner (item 
36 and 37) and risk scenarios (item 38). Moreover, 1-item related to get HIV antibody testing (item 39) is included.

5. Stigma and discrimination towards people living with HIV (SD-HIV). A series of statements that measure solidary behavior towards known and unknown people living with HIV (item 42, 43 and 44). Moreover, items related to empathy and social perception of HIV-positive people (item 40 and 41) are included.

\section{Procedure}

In order to design the assessment tool, a group of experts in health psychology generated a set of statements that represented the main keys of the theoretical models of HIV prevention. Two experts extensively reviewed a bank of 64 items. The quality criteria were syntactic correction, semantic comprehension and adequacy of statements to the construct. The experts evaluated each item scoring from 0 to 5. Questions that had formulation problems were deleted, some statements were rewritten using alternative expressions, and items with similar content were grouped. The corrected version of the instrument was administered to a pilot group. The final version was composed of 44 items.

Participants were collected during the World AIDS Day. The research unit carries out informative and formative activities on the 1st December each year. They were aimed to raise awareness, disseminate knowledge and offer volunteer programs to the young people. Specifically, diptychs on participation about HIV research projects were offered to interested people during 2016. In the first phase, these young people were contacted by the mean of communication preferred to provide them information about the study and confirm their participation (two months). In the second phase, groups of 6-7 participants filled questionnaires in a paper-and-pencil format, in the laboratories of the university research unit (four months). The approximate time to 
complete them was ten minutes. The guidelines of the Spanish data protection law and the Declaration of Helsinki were applied.

\section{Analysis of data}

Participants were randomly divided into two sub-samples to explore and confirm the factorial structure. Sample 1 had 231 people $(40.26 \%$ were male and $59.74 \%$ were female) aged 17 to 26 years $(M=20.48 ; S D=2.17)$. They were included in the Exploratory Factor Analysis (EFA). Sample 2 was consisted of 235 people $(42.16 \%$ were males and $56.84 \%$ were females $)$ aged 17 and 26 years $(\mathrm{M}=19.82, \mathrm{SD}=2.13)$. They were included in the Confirmatory Factor Analysis (CFA). No statistically significant gender and aged differences were found.

Psychometric properties of the questionnaire were evaluated by the Kaiser-MeyerOlkin test (KMO) and Bartlett's test of sphericity, Unweighted least squares (ULS) method and an oblique rotation (direct Oblimin) were used for EFA, structural equation modeling were required for CFA, the Cronbach's $\alpha$ was used as a reliability index, and the relationship among components was calculated by the Pearson's correlation coefficient. The fit indices used were Satorra-Bentler scaled Chi-square ( $\chi 2 \mathrm{~S}-\mathrm{B} / \mathrm{df})$, Normed Fit Index (NFI), Non-normed Fit Index (NNFI), Comparative Fit Index (CFI), and Root Mean Square Error of Approximation (RMSEA). IBM SPSS Statistics 20.0 and EQS 6.1 programs were used for the statistical analysis.

\section{Results}

\section{Structure}

The questionnaire has five dimensions previously commented that assess the main components of HIV prevention. As seen in Table 2, each factor has a certain number of items and a minimum-maximum range of scores. The Cronbach's alpha internal consistency reliability was adequate (between .67 and .74). 


\section{INSERT TABLE 2}

\section{Knowledge about HIV (K-HIV)}

Results of the Kaiser-Meyer-Olkin $(\mathrm{KMO}=.702)$ measure of sampling adequacy and Bartlett's test of sphericity $\left(\chi^{2} 66=577.672, \mathrm{p}<.001\right)$ were appropriate for factor analysis. Consequently, an exploratory factor analysis by weighted least squares and direct Oblimin rotation was conducted. Four subfactors were extracted explaining $52.91 \%$ of the total variance:

- K-HIV 1, called "Level of perceived HIV-information", was made up of 3 items (item 1, 2 and 3) that measured the belief about the own level of information. It explains $21.78 \%$ of variance.

- K-HIV 2, named "Myths about HIV/AIDS", was made up of 3 items (item 4, 5 and 6) that asked misconceptions about HIV infection and people living with HIV. It explains $10.52 \%$ of variance.

- K-HIV 3, called "Level of HIV-information", was made up of 3 items (item 7, 8 and 9) that evaluated the knowledge about routes of HIV transmission. It explains $10.87 \%$ of variance.

- K-HIV 4, named "HIV antibody testing knowledge", was made up of 3 items (item 10, 11 and 12) that examined the information about diagnosis of HIV. It explains $9.74 \%$ of variance.

Confirmatory factor analysis was conducted. The indexes related to the model seemed to be a good fit to the data: $\chi^{2} \mathrm{~S}-\mathrm{B} / \mathrm{df}=1.213, \mathrm{NNFI}=.963, \mathrm{CFI}=.973 ;$ RMSEA $=.022$. In this factor, the Cronbach's alpha obtained was .673.

Self-efficacy and attitudes (SEA)

Results of the Kaiser-Meyer-Olkin (KMO = .679) measure of sampling adequacy and Bartlett's test of sphericity $\left(\chi_{66}^{2}=604.364, \mathrm{p}<.001\right)$ were appropriate for factor 
analysis. Consequently, an exploratory factor analysis with weighted least squares and direct oblimin rotation was conducted. Three subfactors were extracted explaining $55.79 \%$ of the total variance:

- SEA 1, called "Comfort in condom use", was made up of 5 items (item 13, 14, 17, 18 and 19) that assessed the level of safety and feeling of comfort with the condom. It explains $28.33 \%$ of variance.

- SEA 2, named "Condom use negotiation", was made up of 2 items (item 15 and 16) that evaluated the fear of partner rejection after requesting the use of condom. It explains $11.63 \%$ of variance.

- SEA 3, called "knowledge about how to use condoms", was made up of 2 items (item 20 and 21) that examined the knowledge of how to put on a condom correctly. It explains $15.80 \%$ of the variance.

Confirmatory factor analysis was conducted. The indexes related to the model seemed to be a good fit to the data: $\chi^{2} \mathrm{~S}-\mathrm{B} / \mathrm{df}=1.532, \mathrm{NNFI}=.958, \mathrm{CFI}=.972, \mathrm{RMSEA}$ $=.035$. The Cronbach's alpha obtained in this factor was .699.

\section{Condom Use Intentions (CUSEI)}

Results of the Kaiser-Meyer-Olkin $(\mathrm{KMO}=.742)$ measure of sampling adequacy and Bartlett's test of sphericity $\left(\chi^{2} 66=189.997, \mathrm{p}<.001\right)$ were appropriate for factor analysis. Consequently, an exploratory factor analysis with weighted least squares and direct oblimin rotation was conducted. Two subfactors were extracted explaining $62.93 \%$ of the total variance:

- CUSEI 1, named "Behavioral intention to condom use in different sexual practices", was made up of 4 items (item 27, 28, 29 and 30) that assessed the motivation to use a condom in romantic relationships. It explains $43.99 \%$ of variance. 
- CUSEI 2, called "Behavioral intention to condom use with casual partner and drugs use a condom in occasional relationships. It explains $18.94 \%$ of variance.

Confirmatory factor analysis was conducted. The indexes related to the model seemed to be a good fit to the data: $\chi^{2}$ s-B $/ \mathrm{df}=1.525, \mathrm{NNFI}=.934, \mathrm{CFI}=.956, \mathrm{RMSEA}$ $=.061$. In this factor, the Cronbach's alpha obtained was .739.

\section{Safe sexual behavior (SAS-B)}

Results of the Kaiser-Meyer-Olkin $(\mathrm{KMO}=.633)$ measure of sampling adequacy and Bartlett's test of sphericity $\left(\chi^{2} 66=152.388, \mathrm{p}<.001\right)$ were appropriate for factor analysis. Consequently, an exploratory factor analysis with weighted least squares and direct oblimin rotation was conducted. Three subfactors were extracted explaining $74.91 \%$ of the total variance:

- SAS-B 1, called "Vaginal intercourse", was made up of 2 items (item 33 and 36) that assessed the use of condom in vaginal sexual practices. It explains $39.13 \%$ of variance.

- SAS-B 2, named "Anal and oral intercourse", was made up of 2 items (item 34 and 35) that evaluated the use of condom in oral and anal sexual practices. It explains $18.74 \%$ of variance.

- SAS-B 3, called “Occasional intercourse”, was made up of 2 items (item 37 and 38) that examined the use of condom with sporadic partners and under alcohol and drugs effects. It explains $17.03 \%$ of variance.

Confirmatory factor analysis was conducted. The indexes related to the model seemed to be a good fit to the data: $\chi^{2}$ s-B $/ \mathrm{df}=1.577, \mathrm{NNFI}=.939, \mathrm{CFI}=.975, \mathrm{RMSEA}$ $=.068$. The Cronbach's alpha obtained in this factor was .674 . 
Results of the Kaiser-Meyer-Olkin $(\mathrm{KMO}=.675)$ measure of sampling adequacy and Bartlett's test of sphericity $\left(\chi^{2}{ }_{66}=287.081, \mathrm{p}<.001\right)$ were appropriate for factor analysis. Consequently, an exploratory factor analysis with weighted least squares and direct Oblimin rotation was conducted. Two subfactors were extracted explaining $64.28 \%$ of the total variance:

- SD-HIV 1, called "Empathy", was made up of 2 items (item 40 and 41) that assessed the capacity to understand how people live with HIV, that is, the social perception about the feeling that HIV positive people are experiencing. It explains $36.15 \%$ of variance.

- SD-HIV 2, named "Solidarity", was made up of 3 items (item 42, 43 and 44) that evaluated the predisposition to help a friend living with HIV. It explains $28.13 \%$ of variance.

Confirmatory factor analysis was conducted. The indexes related to the model seemed to be a good fit to the data: $\chi^{2}$ s-B $/ \mathrm{df}=1.877, \mathrm{NNFI}=.952, \mathrm{CFI}=.965$, RMSEA $=.076$. The Cronbach's alpha obtained in this factor was .689.

Finally, it should be highlighted that the statistical analysis of items 22, 23, 24, 25, 26 and 39 have not allowed to include them in these previous dimensions. However, they are maintained because their content are relevant for a comprehensive assessment of the preventive aspects of HIV and evaluate main aspects of the theoretical models of HIV prevention. They will be have a qualitative analysis and interpretation.

\section{Normative Data and Correlations}

Significant statistical differences by gender are found in SD-HIV $(\mathrm{p}=.008)$ and CUSEI $(\mathrm{p}=.021)$. Females obtained higher scores than males in stigma and discrimination towards people living with HIV and condom use intentions (see Table 3).

\section{INSERT TABLE 3}


Moreover, all components were related to each other with values ranging from .122 to .499 . As Table 4 shows, there are positive correlations between condom attitudes and knowledge about HIV ( $\mathrm{p}=.001)$, safe sexual behavior $(\mathrm{p}=.002)$, and stigma and discrimination towards people living with HIV $(\mathrm{p}=.016)$. Moreover, condom use intentions and safe sexual behavior showed positive correlations $(\mathrm{p}=.001)$.

\section{INSERT TABLE 4}

\section{Classification of the scores}

A classification system that allows applying a descriptive label to each dimension is showed. The mean T-score range on all scales is from 41 to 59 points. Low scores are within one or two standard deviations of the mean. They indicate deficits in any component; therefore, there is a risk for sexual health. Very low scores are within two or more standard deviations of the mean. They indicate significant problems in any component, thus, an increment of the risk to HIV infection (see Table 5).

\section{INSERT TABLE 5}

\section{Discussion}

This study evaluated the psychometric properties of a brief AIDS Prevention Questionnaire in a sample of Spanish youth. AIDS is a challenge for public health, especially in groups such as MSM or heterosexuals [1, 2]. Correctly and consistent condom use in sexual relationships is the only effective procedure for HIV prevention, other sexually transmitted infections and unwanted pregnancies. The behavior changes models have explained the sexual risk behavior through psychosocial determinants [37]. It is necessary to design brief and easy-apply assessment measures to score broadly the risk factors for HIV infection in the clinical, educational and health settings. Most of the assessment measures reviewed are in English language. There is only one other multi-component questionnaire adapted to the Spanish context, the HIV/AIDS Scale 
164 by Paniagua. But it has 164 items or 65 in the brief version, and it does not include a behavioral component $[37,42]$. The other scales found measure a single component of HIV prevention, for example: HIV knowledge [16], AIDS phobia [25] or HIV risk perception [26].

Our results support a questionnaire that includes 5 factors with adequate internal consistency (between .67 and .74). The first factor is called Knowledge about HIV (KHIV), it has 12 items referred to knowledge about the HIV transmission routes and the HIV-antibody testing, the perceived information or the misconceptions about the disease. This factor explains $51.91 \%$ of variance and has a reliability of 0.67 . The second factor is named Condom Attitudes (CATT), it has 9 items related to the perceived competence, feeling of comfort and security with the condom (for example: buy it, put it on, talk about it, etc.) and fear of rejection for proposing its use to a partner. In this line, Weeks and cols. in 1995, identified the multidimensionality of selfefficacy (use and rejection) [43]. This factor explains $55.79 \%$ of variance and it has a reliability of 0.70 . The third factor is called Condom Use Intention (CUSEI), it has 6 items and is the motivational component of the behavior. After statistical analysis, behavioral intention for condom use with steady partner or in casual relationships have appeared to be as two components separately, maybe because different contextual factors are influencing in each scenario. This factor explains $62.93 \%$ of variance and has a reliability of 0.74 . Similarly, the fourth factor named Safe sexual behavior (SASB) is grouped according to the frequency of condom use. Perhaps this structure relates to the lesser or greater perceived ability to discuss condom use with a partner. It has 6 items, explains $74.91 \%$ of variance and has a reliability of 0.67 . The last factor, called Stigma and discrimination towards people living with HIV (SD-HIV), has 5 items that are subdivided into the attitudinal sphere (empathy) and the behavioral sphere 
(willingness to help a person with HIV). This factor explains $64.28 \%$ of variance and has a reliability of 0.69 .

These factors explain a high percentage of total variance and they are conceptually related to each other. Behavioral intention predicts behavior according to the Theory of Planned Behavior, it is associated to condom use in studies such as those of Jemmott et al. [33] or Asare [44]. Appropriate knowledge about HIV prevention is the main variable to analyze the risk and feel competent to use the condom in sexual interactions [45]. Moreover, feeling competent to use condoms also facilitates its use directly [46, 47].

These findings have limitations that must be addressed in the future studies. First, the questionnaire does not include a factor with the assessment of an attitudinal component. Therefore, it is recommended to use the qualitative part of the questionnaire that asked about perceived susceptibility, perceived severity, perceived fear, or subjective norm, by which professionals may assess the cognitive-affective characteristics of the sexual risk behavior. Secondly, it would be necessary to analyze the test-retest reliability and discriminant validity.

However, this research offers a brief and valid evaluation measure that can be adapted to the needs of health professionals: to identify groups at risk for HIV infection, to design prevention programs or psychological intervention aimed at deficient areas, and to evaluate the effectiveness of treatments applied, identifying what components have changed and what ones have been resistant to change.

\section{References}

(1) European Centre for Disease Prevention and Control, WHO Regional Office for Europe. HIV/AIDS surveillance in Europe 2014. Stockholm: ECDC; 2015. 
http://ecdc.europa.eu/en/publications/Publications/hiv-aids-surveillance-in-Europe2014.pdf.

(2) Área de Vigilancia de VIH y Comportamientos de Riesgo. Vigilancia Epidemiológica del VIH y sida en España: Sistema de Información sobre Nuevos Diagnósticos de VIH y Registro Nacional de Casos de Sida. Plan Nacional sobre el Sida - S.G. de Promoción de la Salud y Epidemiología / Centro Nacional de Epidemiología $\begin{array}{lll}\text { ISCIII. } & \text { Madrid; } & \text { Nov }\end{array}$ https://www.msssi.gob.es/ciudadanos/enfLesiones/enfTransmisibles/sida/vigilancia/Info rmeVIH_SIDA_2017_NOV2017.pdf.

(3) Rosenstock IM. The health belief model and preventive health behavior. Health Educ Monogr. 1974; 2: 354-86.

(4) Fishbein M, Ajzen I. Belief, attitude, intention, and behavior: An introduction to theory and research. Reading, MA: Addison-Wesley; 1975.

(5) Ajzen, I. The theory of planned behavior. Organ Behav Hum Decis Process. 1991; 50: 179-211.

(6) Fisher JD, Fisher WA. Changing AIDS-risk behavior. Psychol Bull. 1992; 111: 455-74.

(7) Bandura A. Health promotion from the perspective of social cognitive theory. Psychol Health. 1998; 13: 623-49.

(8) Reid AE, Aiken LS. (2011) Integration of five health behaviour models: Common strengths and unique contributions to understanding condom use. Psychol Health. 2011; 26(11): 1499-520.

(9) Helweg-Larsen M, Collins BE. (1994). The UCLA Multidimensional Condom Attitudes Scale: Documenting the complex determinants of condom use in college students. Health Psychol. 1994; 13(3): 224-37. 
(10) Boshamer CB, Bruce KE. A scale to measure attitudes about HIV-antibody testing: development and psychometric validation. AIDS Educ Prev. 1999; 11(5): 400-13.

(11) Silva N, Henrique P, Henrique dos Reis C, Silva NM. HIV/AIDS Attitudes Scale: Factorial analysis. J Bras Psiquiatr. 2007; 56(3): 194-200.

(12) Smith EA, Miller JA, Newsome V, Sofolahan YA, Airhihenbuwa CO. Measuring HIV/AIDS-Related Stigma Across South Africa: A Versatile and Multidimensional Scale. Health Educ Behav, 2014; 41(4): 387-91.

(13) Nydegger LA, Ames SL, Stacy AW. The development of a new condom use expectancy scale for at-risk adults. Soc Sci Med. 2015; 143: 179-84.

(14) Golub SA, Garamel KE. Psychometric evaluation of the Condom Barriers and Motivations Scale (CBMS). J Behav Med. 2017; 40(3): 494-505.

(15) Espada JP, Ballester R, Huedo-Medina TB, Secades-Villa R, Orgilés M, MartínezLorca M. Development of a new instrument to assess AIDS-related attitudes among Spanish Youngsters. Anales de Psicología. 2013; 29(1): 83-9.

(16) Carey MP, Schroder KEE. Development and psychometric evaluation of the brief HIV knowledge questionnaire (HIV-KQ-18). AIDS Educ Prev. 2002; 14: 174-84.

(17) Espada JP, Guillén-Riquelme A, Morales A, Orgilés M, Sierra JC. Validación de una escala de conocimiento sobre el VIH y otras infecciones de transmisión sexual en población adolescente. Aten Primaria. 2014; 46(10): 558-64.

(18) Brafford LJ, Beck KH. Development and validation of a condom self-efficacy scale for college students. J Am Coll Health. 1991; 39(5): 219-25.

(19) Baele J, Dusseldorp E, Maes S. (2001). Condom use self-efficacy: effect on intended and actual condom use in adolescents. J Adolesc Health. 2001; 28(5): 421-31. 
(20) Sherman SG, et al. The reliability and validity of the Modified Condom Outcome Expectancy Scale (MCOES) among an international sample of HIV-negative partners of people living with HIV/AIDS. AIDS Care. 2003; 15(3): 359-66.

(21) McCabe BE, Schaefer N, Gattamorta K, et al. Development and Psychometric Evaluation of a Condom Use Self-Efficacy Measure in Spanish and English. HIV Clin Trials. 2016; 17(5): 212-17.

(22) Bell RA, Molitor F, Flynn NM. (1999). Fear of AIDS: Assessment and Implications for Promoting Safer Sex. AIDS Behav. 1999; 3(2): 135-47.

(23) Gullone E, Moore S, Moss S, Boyd C. The Adolescent Risk-taking Questionnaire: development and psychometric evaluation. J Adolesc Res. 2000; 15(2): 231-50.

(24) Napper LE, Fisher DG, Reynolds GL. Development of the Perceived Risk of HIV Scale. AIDS Behav. 2012; 16(4): 1075-83.

(25) Espada JP, Gonzálvez MT, Orgilés M, Morales A. (2013). Multicomponent AIDS Phobia Scale validation with Spanish adolescents. Psicol Conductual. 2013; 21(3): 44960.

(26) Sales JM, Spitalnick J, Milhausen RR, et al. (2009). Validation of the worry about sexual outcomes scale for use in STI/HIV prevention interventions for adolescent females. Health Educ Behav. 2009; 24(1): 140-52.

(27) Dilorio C, Parsons M, Lehr S, Adame D, Carlone J. Measurement of safe sex behavior in adolescents and young adults. Nurs Res. 1992; 41(4): 203-8.

(28) Noar SM, Morokoff PJ, Harlow LL. Condom negotiation in heterosexually active men and women: development and validation of a condom influence strategy questionnaire. Psychol Health. 2002; 17(6): 711-35. 
(29) Whyte J. The Measurement of HIV Risk Level in African American Women Who Dwell in the Southeastern United States. J Assoc Nurses AIDS Care. 2005; 16(6): 4855.

(30) Ballester-Arnal R, Gil-Llario MD, Castro-Calvo J, Giménez-García C. HIV-Risk Index: Development and Validation of a Brief Risk Index for Hispanic Young People. AIDS Behav. 2016; 20: 1796-807.

(31) Scandell DJ, Wlazelek B. A validation study of the AIDS Health Belief Scale. Can J Hum Sex. 2002; 11(1): 41-9.

(32) Nöstlinger Ch, Nideröst S, Platteau T, et al. Sexual Protection Behavior in HIVPositive Gay Men: Testing a Modified Information-Motivation-Behavioral Skills Model. Arch Sex Behav. 2011; 40: 817-27.

(33) Jemmott JB III, Jemmott LS, Fong GT, McCaffree K. (1999). Reducing HIV riskassociated sexual behavior among African American adolescents: testing the generality of intervention effects. Am J Community Psychol. 1999; 27(2): 161-87.

(34) Dancy BL. The development of an ethnically sensitive and gender specific AIDS questionnaire for African American women. Health Values: The Journal of Health Behavior, Education \& Promotion. 1992; 15(6): 49-54.

(35) Perkel AK. Development and testing of the AIDS Psychosocial Scale. Psychol Rep. 1992; 71(3): 767-78.

(36) Trezza GR. HIV knowledge and stigmatization of persons with AIDS: implications for the development of HIV education for young adults. Prof Psychol Res. 1994; 25(2): 141-8.

(37) Paniagua FA, O’Boyle M, Wagner KD, et al. AIDS related items for developing an AIDS questionnaire for children and adolescents. J Adolesc Res. 1994; 9(3): 311-39. 
(38) Hagan TM. The development of the AIDS Risk Questionnaire. Dissertation Abstracts International: Section B: The Sciences and Engineering. 1998; 58(10B): 5693. (39) Davis C, Tang C, Chan F, Noel B. The development and validation of the. International Aids Questionnaire-Chinese version (IAQ-C). Educ Psychol Meas. 1999; 59(3): 481-91.

(40) Xinying S, Wenbin G, Chun Ch. Reliability and Validity of a Questionnaire on Knowledge, Beliefs and Intentions related to AIDS/Safe Sex for University Students. CMHJ. 2004; 18(6): 408-10.

(41) Pratte K, Whitesell N, McFarlane M, Bull S. Factor analyses of condom attitudes, norms, and self-efficacy measures in diverse samples. J Nurs Meas. 2010; 18(3): 15375.

(42) Bermúdez MP, Sánchez AI, Buela-Casal G. Spanish adaptation of the HIV/AIDS164 Scale. Rev Mex Psicol. 2003; 20(1): 95-111.

(43) Weeks K, Levy SR, Zhu Ch, Perhats C, Handler A, Flay BR. Impact of a socialbased AIDS prevention program on young adolescents' self-efficacy skills. Health Educ Res. 1995; 10(3): 329-44.

(44) Asare M. Using the Theory of Planned Behavior to determine the condom use behavior among college students. Am J Health Stud. 2015; 30(1): 43-50.

(45) Todd S. HIV in young adults: an exploration of knowledge and risk. Coll Stud J. 2015; 49(3): 427-37.

(46) Giménez-García C, Ballester-Arnal R, Gil-Llario MD, Cárdenas-López G, DuranBaca X. Culture as an Influence on the Perceived Risk of HIV Infection: A Differential Analysis Comparing Young People from Mexico and Spain. J Community Health. 2013; 38(3): 434-42. 
(47) Nesoff ED, Dunkle K, Lang D. The impact of condom use negotiation self-efficacy and partnership patterns on consistent condom use among college-educated women. Health Educ Behav. 2016; 43(1): 61-7. 
Table 2. Questionnaire components, number of statements, score range and Cronbach's alpha

\begin{tabular}{lccc}
\hline Component & Item & Minimum and & \\
& & maximum values & \\
\hline K-HIV & $1,2,3,4,5,6,7,8,9,10,11,12$ & $0-24$ & .67 \\
\hline SEA & $13,14,15,16,17,18,19,20,21$ & $9-54$ & .70 \\
\hline CUSEI & $27,28,29,30,31,32$ & $0-18$ & .74 \\
\hline SAS-B & $33,34,35,36,37,38$ & $0-18$ & .67 \\
\hline SD-HIV & $40,41,42,43,44$ & $0-206$ & .69 \\
\hline
\end{tabular}


Table 3. Descriptive statistics and gender differences (t-test)

\begin{tabular}{|c|c|c|c|c|}
\hline \multirow[b]{2}{*}{ Component } & \multicolumn{3}{|c|}{$\mathrm{M}(\mathrm{SD})$} & \multirow[b]{2}{*}{$\mathrm{t}$} \\
\hline & $\begin{array}{l}\text { Total sample } \\
\qquad(\mathrm{n}=466)\end{array}$ & $\begin{array}{c}\text { Male } \\
(\mathrm{n}=192)\end{array}$ & $\begin{array}{l}\text { Female } \\
(n=274)\end{array}$ & \\
\hline K-HIV & $17.85(3.12)$ & $18.09(2.95)$ & $17.67(3.24)$ & 1.352 \\
\hline SEA & $45.01(5.71)$ & $44.71(5.73)$ & 45.23 (5.69) & -.935 \\
\hline CUSEI & $12.81(3.71)$ & $12.25(3.43)$ & 13.74 (3.99) & $-2.342^{*}$ \\
\hline SAS-B & $9.44(3.40)$ & $9.16(3.53)$ & $9.78(3.24)$ & -1.010 \\
\hline SD-HIV & $176.76(27.45)$ & $172.50(30.34)$ & $179.64(24.96)$ & $-2.647 * *$ \\
\hline
\end{tabular}


Table 4. Pearson's correlation coefficient between questionnaire components

\begin{tabular}{cccccc}
\hline & K-HIV & SEA & CUSEI & SAS-B & SD-HIV \\
\hline K-HIV & -- & $.220 * * *$ & -.023 & .119 & -.005 \\
SEA & & -- & .034 & $.282 * *$ & $.122 *$ \\
CUSEI & & -- & $.499 * * *$ & .011 \\
SAS-B & & & -- & -.017 \\
SD-HIV & & & & -- \\
\hline$* \mathrm{p}<.05 ; * * \mathrm{p}<.01 ; * * * \mathrm{p}<.001$ & & & &
\end{tabular}


Table 5. Profiling scores

\begin{tabular}{ccccccc}
\hline K-HIV & SEA & CUSEI & SAS-B & SD-HIV & \multicolumn{2}{c}{ T-scores } \\
\hline$>23$ & $>52$ & $>17$ & $>17$ & $>205$ & $<70$ & Very high \\
$20-22$ & 51 & & $13-16$ & - & $60-69$ & High \\
$14-19$ & $40-50$ & $10-16$ & $7-12$ & $150-204$ & $41-59$ & Average range \\
$11-13$ & $34-39$ & $7-9$ & $3-6$ & $122-149$ & $31-40$ & Low \\
$<10$ & $<33$ & $<5$ & $<2$ & $<121$ & $<30$ & Very low \\
\hline
\end{tabular}


Table 1. Summary of tools for assessing main components of HIV prevention

\begin{tabular}{|c|c|c|c|c|c|c|c|}
\hline Name & Year & Authors & Location & Population & $\begin{array}{l}\text { No. Of } \\
\text { items }\end{array}$ & Subscales & $\begin{array}{l}\text { Alpha de } \\
\text { Cronbach }\end{array}$ \\
\hline $\begin{array}{l}\text { Condom Use Self- } \\
\text { Efficacy Scale [18] }\end{array}$ & 1991 & L.J. Brafford and K.H. Beck & USA & 803 college students & 28-items & $\begin{array}{l}\text { 1: personal experience with } \\
\text { condoms, } 2 \text { : embarrassment } \\
\text { at purchase, } 3 \text { : alcohol use, } \\
\text { 4: not wanting to offend } \\
\text { with the implication of } \\
\text { uncleanliness, 5: reduction } \\
\text { in excitement, } 6 \text { : loss of } \\
\text { spontaneity, } 7: \text { breaking the } \\
\text { mood, 8: not being prepared, } \\
\text { 9: unsure of partner's feeling } \\
\text { about condoms, 10: } \\
\text { embarrassment, 11: } \\
\text { communication with partner, } \\
\text { 12: embarrassment about } \\
\text { talking about condoms, } 13 \text { : } \\
\text { afraid of partner's refusal of } \\
\text { condom use, 14: ability to } \\
\text { maintain an erection, and } 15 \text { : } \\
\text { fear of reputation }\end{array}$ & .91 \\
\hline $\begin{array}{l}\text { The Safe Sex Behavior } \\
\text { Questionnaire [27] }\end{array}$ & 1992 & $\begin{array}{l}\text { C. DiIorio, M. Parsons, S. Lehr, D } \\
\text { Adame and J. Carlone }\end{array}$ & USA & 531 college freshmen & 27-items & $\begin{array}{l}\text { 1: sexual behaviors, } 2 \text { : } \\
\text { condom usage, } 3: \text { high risk } \\
\text { sexual behaviors, } 4: \text { sexual } \\
\text { communication and } \\
\text { negotiation }\end{array}$ & $\begin{array}{l}.52 \text { to } .85 \\
\text { (individual } \\
\text { subscales) }\end{array}$ \\
\hline $\begin{array}{l}\text { Multidimensional } \\
\text { Condom Attitudes Scale } \\
\text { [9] }\end{array}$ & 1994 & M. Helweg-Larsen and B.E. Collins & USA & $\begin{array}{l}239 \text { undergraduate } \\
\text { students } \\
\text { Age ranged from } 15 \text { to } \\
35 \text { years }\end{array}$ & 25-items & $\begin{array}{l}\text { 1: Reliability and } \\
\text { Effectiveness, 2: Pleasure, 3: } \\
\text { Identity Stigma, 4: } \\
\text { Embarrassment About } \\
\text { Negotiation and Use, 5: } \\
\text { Embarrassment About }\end{array}$ & $\begin{array}{l}.62 \text { to } .94 \\
\text { (individual } \\
\text { subscales) }\end{array}$ \\
\hline
\end{tabular}




\begin{tabular}{|c|c|c|c|c|c|c|c|}
\hline & & & & & & Purchase, & \\
\hline $\begin{array}{l}\text { HIV-Antibody Testing } \\
\text { Attitude Scale [10] }\end{array}$ & 1999 & C.B. Boshamer and K.E. Bruce & USA & $\begin{array}{l}156 \text { heterosexual } \\
\text { students } \\
\text { Age ranged from } 17 \text { to } \\
37 \text { years }\end{array}$ & 32-item & $\begin{array}{l}\text { 1: Friends concerns about } \\
\text { HIV antibody testing, } 2: \\
\text { Family concerns about HIV } \\
\text { antibody testing, 3: Concern } \\
\text { about public opinion of HIV } \\
\text { antibody testing, } 4: \\
\text { Concerns about } \\
\text { confidentiality of HIV } \\
\text { antibody testing }\end{array}$ & .88 \\
\hline $\begin{array}{l}\text { Fear-of-AIDS Instrument } \\
{[22]}\end{array}$ & 1999 & R.A. Bell, F. Molitor and N.M. Flynn & USA & $\begin{array}{l}608 \text { men and women at } \\
\text { the AIDS Foundation's } \\
\text { anonymous HIV test site }\end{array}$ & 40-items & $\begin{array}{l}\text { 1: Infection Fear, 2: Partner } \\
\text { Betrayal, 3: Economic } \\
\text { Consequences, 4: Society's } \\
\text { Response, 5: Testing } \\
\text { Concerns, 6: Casual Contact, } \\
\text { 7: Medical Procedures, 8: } \\
\text { Safe Sex Communication } \\
\text { Apprehension }\end{array}$ & $\begin{array}{l}.87 \text { to } .97 \\
\text { (individual } \\
\text { subscales) }\end{array}$ \\
\hline $\begin{array}{l}\text { Risk-Taking } \\
\text { Questionnaire [23] }\end{array}$ & 2000 & $\begin{array}{l}\text { E. Gullone, S. Moore, S. Moss and C. } \\
\text { Boyd }\end{array}$ & Australia & $\begin{array}{l}570 \text { and } 925 \text { adolescents } \\
\text { Age ranged from } 11 \text { to } \\
18 \text { years }\end{array}$ & 22-items & $\begin{array}{l}\text { 1: thrill-seeking behaviors, } \\
\text { 2: rebellious behaviors, } 3 \text { : } \\
\text { reckless behaviors (having } \\
\text { unprotected sex included), 4: } \\
\text { antisocial behaviors }\end{array}$ & $\begin{array}{l}.66 \text { to } .80 \\
\text { (individual } \\
\text { subscales) }\end{array}$ \\
\hline $\begin{array}{l}\text { Specific Condom Use } \\
\text { Self-efficacy Scales [19] }\end{array}$ & 2001 & J. Baele, E. Dusseldorp and S. Maes & Belgium & $\begin{array}{l}424 \text { male and female } \\
\text { sexually experienced } \\
\text { and inexperienced } \\
\text { adolescents } \\
\text { Average age of } 17 \text { years }\end{array}$ & 37-items & $\begin{array}{l}\text { 1: technical skills, } 2 \text { : image } \\
\text { confidence, 3: emotion } \\
\text { control, 4: purchase, 5: } \\
\text { assertiveness, 6: sexual } \\
\text { control }\end{array}$ & $\begin{array}{l}.65 \text { to } .84 \\
\text { (individual } \\
\text { subscales) }\end{array}$ \\
\hline $\begin{array}{l}\text { Brief HIV Knowledge } \\
\text { Questionnaire [16] }\end{array}$ & 2002 & M.P. Carey and K.E.E. Schroder & USA & $\begin{array}{l}1019 \text { low-income men } \\
\text { and women } \\
\text { Average age of } 33.99 \\
\text { years }\end{array}$ & 18-items & Unidimensional & $\begin{array}{l}0.75 \text { to } 0.89 \\
\text { (across } \\
\text { samples) }\end{array}$ \\
\hline $\begin{array}{l}\text { Condom Influence } \\
\text { Strategy Questionnaire } \\
{[28]}\end{array}$ & 2002 & $\begin{array}{l}\text { S.M. Noar, P.J. Morokoff and L.L. } \\
\text { Harlow }\end{array}$ & USA & $\begin{array}{l}625 \text { college students } \\
\text { Age ranged from } 18 \text { to } \\
22 \text { years }\end{array}$ & 36-items & $\begin{array}{l}\text { 1: Withholding sex, 2: } \\
\text { Direct request, 3: Seduction, } \\
\text { 4: Relationship } \\
\text { conceptualizing, 5: Risk }\end{array}$ & $\begin{array}{l}.83 \text { to } .93 \\
\text { (individual } \\
\text { subscales) }\end{array}$ \\
\hline
\end{tabular}




\begin{tabular}{|c|c|c|c|c|c|c|c|}
\hline & & & & & & $\begin{array}{l}\text { (STD) information, 6: } \\
\text { Deception }\end{array}$ & \\
\hline $\begin{array}{l}\text { Modified Condom } \\
\text { Outcome } \\
\text { Expectancy Scale [20] }\end{array}$ & 2003 & $\begin{array}{l}\text { S.G. Sherman, D.A. Celentano, J.W. } \\
\text { McGrath, S.E. Chard, R.R. } \\
\text { Gangakhedkar, N. Joglekar, R. } \\
\text { Malhotra-Kohli, M. Kamya and A. } \\
\text { Fullen }\end{array}$ & USA & $\begin{array}{l}100 \mathrm{HIV} \text {-negative } \\
\text { sexual partners of HIV- } \\
\text { infected individuals }\end{array}$ & 9-items & $\begin{array}{l}\text { Two-factors analogous to } \\
\text { two of the five factors in the } \\
\text { original COES (partner } \\
\text { reaction and positive self- } \\
\text { evaluation) }\end{array}$ & .80 \\
\hline $\begin{array}{l}\text { HIV Risk Behavior } \\
\text { Questionnaire [29] }\end{array}$ & 2005 & J. Whyte & USA & $\begin{array}{l}304 \text { African American } \\
\text { women } \\
\text { Average age of } 23.8 \\
\text { years }\end{array}$ & 25-items & $\begin{array}{l}\text { 1: barrier/fluid avoidance } \\
\text { modalities, } 2 \text { : survival sex, } \\
\text { 3: sexual communications, } \\
\text { 4: factors that increase } \\
\text { sexual risk }\end{array}$ & .82 \\
\hline HIV/AIDS Attitudes [11] & 2007 & $\begin{array}{l}\text { N. Silva, P. Henrique, C. Henrique } \\
\text { and N.M. Silva }\end{array}$ & Brazil & $\begin{array}{l}549 \text { high and elementary } \\
\text { school level students } \\
\text { Age ranged from } 13 \text { to } \\
51 \text { years }\end{array}$ & 47-item & $\begin{array}{l}\text { 1: Technical / Scientific } \\
\text { Information Perception } \\
\text { General Factor, 2: Technical } \\
\text { / Scientific Information } \\
\text { Perception Factor versus } \\
\text { Sexuality and Prejudice, 3: } \\
\text { Technical / Scientific } \\
\text { Information } \\
\text { Perception Factor in Drug } \\
\text { Abuse }\end{array}$ & .859 \\
\hline $\begin{array}{l}\text { Worry about sexual } \\
\text { outcomes [26] }\end{array}$ & 2009 & $\begin{array}{l}\text { J.M. Sales, J. Spitalnick, R.R. } \\
\text { Milhausen, G.M. Wingood, R.J. } \\
\text { DiClemente, L.F. Salazar and R.A. } \\
\text { Crosby }\end{array}$ & USA & $\begin{array}{l}522 \text { African-American } \\
\text { female adolescents } \\
\text { Age ranged from } 14 \text { to } \\
18 \text { years }\end{array}$ & 10-items & $\begin{array}{l}\text { 1: STI/HIV worry, 2: } \\
\text { pregnancy worry }\end{array}$ & .87 \\
\hline $\begin{array}{l}\text { Perceived Risk of HIV } \\
\text { Scale [24] }\end{array}$ & 2012 & $\begin{array}{l}\text { L.E. Napper, D.G. Fisher and G.L. } \\
\text { Reynolds }\end{array}$ & USA & $\begin{array}{l}785 \text { clients of HIV } \\
\text { testing and prevention } \\
\text { services } \\
\text { Age ranged from } 18 \text { to } \\
79 \text { years }\end{array}$ & 8-items & Unidimensional & .88 \\
\hline $\begin{array}{l}\text { Multicomponent } \\
\text { AIDS Phobia Scale [25] }\end{array}$ & 2013 & $\begin{array}{l}\text { J.P. Espada, M.T. Gonzálvez, M. } \\
\text { Orgilés and A. Morales }\end{array}$ & Spain & $\begin{array}{l}832 \text { secondary students } \\
\text { Age ranged from } 14 \text { to } \\
18 \text { years }\end{array}$ & 20-items & Two-factor & .77 \\
\hline HIV Attitudes Scale [15] & 2013 & $\begin{array}{l}\text { J.P. Espada, R. Ballester, T.B. Huedo- } \\
\text { Medina, R. Secades-Vill, M. Orgilés }\end{array}$ & Spain & $\begin{array}{l}1216 \text { high school } \\
\text { students }\end{array}$ & 12-items & $\begin{array}{l}\text { 1: Attitudes toward safe sex } \\
\text { when there are obstacles; } 2 \text { : }\end{array}$ & .77 \\
\hline
\end{tabular}




\begin{tabular}{|c|c|c|c|c|c|c|c|}
\hline & & and M. Martínez-Lorca & & $\begin{array}{l}\text { Age ranged from } 15 \text { to } \\
17 \text { years }\end{array}$ & & $\begin{array}{l}\text { Attitudes toward HIV } \\
\text { testing; 3: Attitudes toward } \\
\text { condom use; 4: Attitudes } \\
\text { toward people living with } \\
\text { HIV/AIDS }\end{array}$ & \\
\hline $\begin{array}{l}\text { HIV/AIDS Stigma Scale } \\
\text { [12] }\end{array}$ & 2014 & $\begin{array}{l}\text { E.A. Smith, J.A. Miller, V. Newsome, } \\
\text { Y.A. Sofolahan and C.O. } \\
\text { Airhihenbuwa }\end{array}$ & USA & $\begin{array}{l}1195 \text { South Africans } \\
\text { Average age of } 35.8 \\
\text { years }\end{array}$ & 12-items & $\begin{array}{l}\text { 1: Government } \\
\text { Support, 2: Shame and } \\
\text { Rejection, 3: Individual } \\
\text { Support }\end{array}$ & $\begin{array}{l}.67 \text { to } .80 \\
\text { (individual } \\
\text { subscales) }\end{array}$ \\
\hline $\begin{array}{l}\text { HIV and other STI } \\
\text { Knowledge Scale [17] }\end{array}$ & 2014 & $\begin{array}{l}\text { J.P. Espada, A. Guillén-Riquelme, A. } \\
\text { Morales, M. Orgilés and J.C. Sierra }\end{array}$ & Spain & $\begin{array}{l}1570 \text { adolescents } \\
\text { Age ranged from } 13 \text { to } \\
17 \text { years }\end{array}$ & 24-items & $\begin{array}{l}\text { 1: General knowledge about } \\
\text { HIV, 2: Condom as a } \\
\text { protective method, 3: Routes } \\
\text { of HIV transmission, 4: } \\
\text { prevention of HIV, and 5: } \\
\text { other sexually transmitted } \\
\text { infections }\end{array}$ & $\begin{array}{l}0.65 \text { to } 0.85 \\
\text { (individual } \\
\text { subscales) }\end{array}$ \\
\hline $\begin{array}{l}\text { Condom Use Expectancy } \\
\text { Scale [13] }\end{array}$ & 2015 & $\begin{array}{l}\text { L.A. Nydegger, S.L. Ames and A.W. } \\
\text { Stacy }\end{array}$ & USA & $\begin{array}{l}440 \text { people in drug } \\
\text { programs }\end{array}$ & 18-items & $\begin{array}{l}\text { 1: Positive outcomes, } 2 \text { : } \\
\text { Negative } \\
\text { Outcomes, 3: Safe sex } \\
\text { outcomes }\end{array}$ & $\begin{array}{l}.73 \text { to } .93 \\
\text { (individual } \\
\text { subscales) }\end{array}$ \\
\hline $\begin{array}{l}\text { Condom Use Self- } \\
\text { efficacy Measure [21] }\end{array}$ & 2016 & $\begin{array}{l}\text { B.E. McCabe, N. Schaefer, K. } \\
\text { Gattamorta, N. Villegas, R. Cianelli, } \\
\text { V.B. Mitrani and N. Peragallo }\end{array}$ & USA & 320 Hispanic women & 15-items & Unidimensional & .92 \\
\hline HIV-Risk Index [30] & 2016 & $\begin{array}{l}\text { R. Ballester-Arnal, M.D. Gil-Llario, } \\
\text { J. Castro-Calvo and C. Giménez- } \\
\text { García }\end{array}$ & Spain & $\begin{array}{l}9861 \text { young people } \\
\text { Age ranged from } 18 \text { to } \\
30 \text { years }\end{array}$ & 9-items & $\begin{array}{l}\text { 1: direct sexual risk } \\
\text { indicators, } 2 \text { :indirect sexual } \\
\text { risk indicators }\end{array}$ & .79 \\
\hline $\begin{array}{l}\text { Condom Barriers and } \\
\text { Motivations Scale }\end{array}$ & 2017 & S.A. Golub and K.E. Gamarel & USA & $\begin{array}{l}473 \text { men who reported } \\
\text { not taking PrEP and } \\
301 \text { men elected to } \\
\text { begin PrEP } \\
\text { Average age of } 32.99 \\
\text { and } 33.91 \text { years }\end{array}$ & 16-items & $\begin{array}{l}\text { 1: Pleasure reduction } \\
\text { barriers, } 2 \text { : Perceived partner } \\
\text { pressure barriers, } 3 \text { : Risk } \\
\text { reduction motivations, } 4 \text { : } \\
\text { Intimacy interference } \\
\text { barriers }\end{array}$ & $\begin{array}{l}0.74 \text { to } 0.83 \\
\text { (individual } \\
\text { subscales) }\end{array}$ \\
\hline
\end{tabular}


Appendix 1. Answer sheet and correction criteria of the AIDS Prevention Questionnaire in Spanish language.

1. ¿Has recibido en alguna ocasión información sobre alguno de los siguientes temas?

\begin{tabular}{|l|c|c|}
\hline & Sí & No \\
\hline 1.1. Sexualidad & 1 & 0 \\
\hline 1.2. Métodos anticonceptivos & 1 & 0 \\
\hline 1.3. Infecciones de trasmisión sexual & 1 & 0 \\
\hline 1.4. VIH/SIDA & 1 & 0 \\
\hline
\end{tabular}

2. ¿Cómo consideras tu nivel de información y conocimiento sobre la prevención del VIH/Sida?

\begin{tabular}{|c|c|c|c|}
\hline Malo & Regular & Bueno & Muy bueno \\
\hline 0 & 1 & 2 & 3 \\
\hline
\end{tabular}

3. ¿De quién o cómo has obtenido información acerca del VIH/Sida?

\begin{tabular}{|l|c|c|}
\hline & Si & No \\
\hline 3.1. Padre o madre & 1 & 0 \\
\hline 3.2. Amigos & 1 & 0 \\
\hline 3.3. Profesores & 1 & 0 \\
\hline 3.4. Charlas o talleres formativos & 1 & 0 \\
\hline 3.5. Campañas informativas & 1 & 0 \\
\hline
\end{tabular}

4. ¿A través de cuáles de las siguientes prácticas sexuales se puede transmitir el VIH si no se utiliza el preservativo?

\begin{tabular}{|l|c|c|}
\hline & $\mathrm{Si}$ & No \\
\hline 4.1. Masturbaciones mutuas & 0 & 1 \\
\hline 4.2. Sexo oral & 1 & 0 \\
\hline 4.3. Coito vaginal & 1 & 0 \\
\hline 4.4. Coito anal & 1 & 0 \\
\hline
\end{tabular}

5. ¿Me pueden transmitir el VIH si practico únicamente el sexo oral?

\begin{tabular}{|c|c|}
\hline Si & No \\
\hline 1 & 0 \\
\hline 0 & 1 \\
\end{tabular}




\begin{tabular}{|l|c|c|}
\hline 7. ¿A simple vista se puede saber si una persona es portadora del VIH? & 0 & 1 \\
\hline $\begin{array}{l}\text { 8. ¿Una persona afectada por el VIH puede transmitir la infección aunque no } \\
\text { presente síntomas? }\end{array}$ & 1 & 0 \\
\hline $\begin{array}{l}\text { 9. ¿La mayoría de las personas que conviven con el VIH muestran síntomas de } \\
\text { estar enfermos enseguida? }\end{array}$ & 0 & 1 \\
\hline $\begin{array}{l}\text { 10. ¿Sabes dónde puedes realizarte las pruebas diagnósticas del VIH? } \\
\text { 11. ¿Dar positivo en estas pruebas implica desarrollar el SIDA con posterioridad? }\end{array}$ & 0 & 1 \\
\hline $\begin{array}{l}\text { 12. ¿Conoces la existencia de un periodo ventana para la realización de las pruebas } \\
\text { diagnósticas del VIH? }\end{array}$ & 1 & 0 \\
\hline
\end{tabular}

\begin{tabular}{|c|c|c|c|c|c|}
\hline & $\begin{array}{l}\mathrm{C} \\
\mathrm{o} \\
\mathrm{m} \\
\mathrm{p} \\
\mathrm{le} \\
\mathrm{ta} \\
\mathrm{m} \\
\mathrm{e} \\
\mathrm{n} \\
\mathrm{te} \\
\mathrm{e} \\
\mathrm{n} \\
\mathrm{d} \\
\mathrm{e} \\
\mathrm{s} \\
\mathrm{a} \\
\mathrm{c} \\
\mathrm{u} \\
\mathrm{e} \\
\mathrm{r} \\
\mathrm{d} \\
\mathrm{o}\end{array}$ & $\begin{array}{l}\mathrm{A} \\
\mathrm{l} \\
\mathrm{g} \\
\mathrm{o} \\
\mathrm{e} \\
\mathrm{n} \\
\mathrm{d} \\
\mathrm{e} \\
\mathrm{s} \\
\mathrm{a} \\
\mathrm{c} \\
\mathrm{u} \\
\mathrm{e} \\
\mathrm{r} \\
\mathrm{d} \\
\mathrm{o}\end{array}$ & $\begin{array}{l}\mathrm{u} \\
\mathrm{e}\end{array}$ & $\begin{array}{l}\mathrm{A} \\
\mathrm{l} \\
\mathrm{g} \\
\mathrm{o} \\
\mathrm{d} \\
\mathrm{e} \\
\mathrm{a} \\
\mathrm{c} \\
\mathrm{u} \\
\mathrm{e} \\
\mathrm{r} \\
\mathrm{d} \\
\mathrm{o}\end{array}$ & $\begin{array}{l}\mathrm{a} \\
\mathrm{c} \\
\mathrm{u} \\
\mathrm{e} \\
\mathrm{r} \\
\mathrm{d} \\
\mathrm{o}\end{array}$ \\
\hline 13. Me siento/sentiría cómodo/a o seguro/a a la hora c & 1 & 2 & 3 & 4 & 5 \\
\hline
\end{tabular}




\begin{tabular}{|l|l|l|l|l|l|}
\hline comprar preservativos & & & & & \\
\hline $\begin{array}{l}\text { 14. Me resultaría cómodo hablar acerca de la utilización del } \\
\text { preservativo con una pareja antes de comenzar la relación } \\
\text { sexual }\end{array}$ & 1 & 2 & 3 & 4 & 5 \\
\hline $\begin{array}{l}\text { 15. Si tengo que sugerir a una pareja que usemos el } \\
\text { preservativo, tengo/tendría miedo de que él/ella me rechace }\end{array}$ & 5 & 4 & 3 & 2 & 1 \\
\hline $\begin{array}{l}\text { 16. No me siento/sentiría seguro/a a la hora de sugerir el } \\
\text { uso del preservativo a una nueva pareja ya que él /ella } \\
\text { podría pensar que lo hago porque creo que tiene una ITS }\end{array}$ & 5 & 4 & 3 & 2 & 1 \\
\hline $\begin{array}{l}\text { 17. Estoy seguro/a de que recordaría utilizar el preservativo } \\
\text { aunque haya consumido alcohol u otras drogas }\end{array}$ & 1 & 2 & 3 & 4 & 5 \\
\hline $\begin{array}{l}\text { 18. Me siento/sentiría incómodo/a a la hora de ponerme el } \\
\text { condón o ponérselo a mi pareja }\end{array}$ & 5 & 4 & 3 & 2 & 1 \\
\hline $\begin{array}{l}\text { 19. Estoy seguro de que podría parar aún en el momento de } \\
\text { mayor excitación para ponerme el condón o ponérselo a mi } \\
\text { pareja }\end{array}$ & 1 & 2 & 3 & 4 & 5 \\
\hline $\begin{array}{l}\text { 20. Sé cómo utilizar el preservativo en mis relaciones } \\
\text { sexuales }\end{array}$ & 1 & 2 & 3 & 4 & 5 \\
\hline $\begin{array}{l}\text { 21. Sé en qué aspectos tengo que fijarme para el uso del } \\
\text { preservativo. }\end{array}$ & 1 & 2 & 3 & 4 & 5 \\
\hline
\end{tabular}

22. Señala de 0 a 100 la probabilidad o el riego que percibes de infectarte con el VIH:

23. Señala de 0 a 100 el temor que te produce la posibilidad de infectarte con el VIH:

24. Dirías que el VIH/Sida es una enfermedad:

\begin{tabular}{|c|c|c|c|}
\hline Leve & Moderada & Grave & Fatal \\
\hline 0 & 1 & 2 & 3 \\
\hline
\end{tabular}

25. ¿Hasta qué punto consideras el preservativo como un método fiable de prevención sexual del VIH?

\begin{tabular}{|c|c|c|c|}
\hline Nada & Algo & Bastante & Mucho \\
\hline 0 & 1 & 2 & 3 \\
\hline
\end{tabular}

\begin{tabular}{|l|c|c|}
\cline { 2 - 3 } \multicolumn{1}{c|}{ 26. ¿Entre la mayoría de la gente importante para ti está bien visto el uso del } & 1 & 0 \\
\hline
\end{tabular}


preservativo?

\begin{tabular}{|c|c|c|c|c|}
\hline & $\begin{array}{l}\mathrm{N} \\
\mathrm{u} \\
\mathrm{n} \\
\mathrm{c} \\
\mathrm{a}\end{array}$ & $\begin{array}{l}\mathrm{g} \\
\mathrm{u} \\
\mathrm{n} \\
\mathrm{a} \\
\mathrm{s} \\
\mathrm{v} \\
\mathrm{e} \\
\mathrm{c} \\
\mathrm{e} \\
\mathrm{s}\end{array}$ & $\begin{array}{l}\text { B } \\
\mathrm{a} \\
\mathrm{st} \\
\mathrm{a} \\
\mathrm{n} \\
\mathrm{te} \\
\mathrm{s} \\
\mathrm{v} \\
\mathrm{e} \\
\mathrm{c} \\
\mathrm{e} \\
\mathrm{s}\end{array}$ & $\begin{array}{l}\mathrm{S} \\
\text { ie } \\
\mathrm{m} \\
\mathrm{p} \\
\mathrm{r} \\
\mathrm{e}\end{array}$ \\
\hline $\begin{array}{l}\text { 27. ¿Con qué frecuencia tienes la intención de utilizar el } \\
\text { preservativo en el coito vaginal? }\end{array}$ & 0 & 1 & 2 & 3 \\
\hline $\begin{array}{l}\text { 28. ¿Con qué frecuencia tienes la intención de utilizar el } \\
\text { preservativo en el sexo oral? }\end{array}$ & 0 & 1 & 2 & 3 \\
\hline $\begin{array}{l}\text { 29. ¿Con qué frecuencia tienes la intención de utilizar el } \\
\text { preservativo en el coito anal? }\end{array}$ & 0 & 1 & 2 & 3 \\
\hline $\begin{array}{l}\text { 30. ¿Con qué frecuencia tienes la intención de utilizar el } \\
\text { preservativo en relaciones con pareja estable? }\end{array}$ & 0 & 1 & 2 & 3 \\
\hline $\begin{array}{l}\text { 31. ¿Con qué frecuencia tienes la intención de utilizar el } \\
\text { preservativo en relaciones con pareja esporádica? }\end{array}$ & 0 & 1 & 2 & 3 \\
\hline $\begin{array}{l}\text { 32. ¿Con qué frecuencia tienes la intención de utilizar el } \\
\text { preservativo cuando has consumido alcohol o drogas? }\end{array}$ & 0 & 1 & 2 & 3 \\
\hline $\begin{array}{l}\text { 33. ¿Con qué frecuencia utilizas el preservativo en el coito } \\
\text { vaginal? }\end{array}$ & 0 & 1 & 2 & 3 \\
\hline 34. ¿Con qué frecuencia utilizas el preservativo en el sexo oral? & 0 & 1 & 2 & 3 \\
\hline 35. ¿Con qué frecuencia utilizas el preservativo en el coito anal? & 0 & 1 & 2 & 3 \\
\hline $\begin{array}{l}\text { 36. ¿Con qué frecuencia utilizas el preservativo en relaciones con } \\
\text { pareja estable? }\end{array}$ & 0 & 1 & 2 & 3 \\
\hline $\begin{array}{l}\text { 37. ¿Con qué frecuencia utilizas el preservativo en relaciones con } \\
\text { pareja esporádica? }\end{array}$ & 0 & 1 & 2 & 3 \\
\hline $\begin{array}{l}\text { 38. ¿Con qué frecuencia utilizas el preservativo cuando has } \\
\text { consumido alcohol o drogas? }\end{array}$ & 0 & 1 & 2 & 3 \\
\hline
\end{tabular}




\begin{tabular}{|l|c|c|}
\cline { 2 - 3 } \multicolumn{1}{c|}{} & Sí & No \\
\hline 39. ¿Te has realizado la prueba diagnóstica del VIH alguna vez? & 1 & 0 \\
\hline
\end{tabular}

40. En una escala de 0 a 100 ¿cuánto dirías que sufre un enfermo con VIH desde el punto de vista físico y social?:

41. En una escala de 0 a 100, ¿hasta qué punto piensas que la sociedad deberías ser más comprensiva y solidaria con los enfermos de VIH?:

\begin{tabular}{|l|c|c|}
\cline { 2 - 3 } \multicolumn{1}{c|}{} & Sí & No \\
\hline 42. ¿Dejarías de ver por completo a un amigo si te enteraras que tiene VIH/Sida? & 0 & 1 \\
\hline 43. ¿Cuidarías de un amigo que tuviera VIH/Sida? & 1 & 0 \\
\hline 44. ¿Evitarías conocer a una persona que sabes que tiene VIH/Sida? & 0 & 1 \\
\hline
\end{tabular}

Sistema de corrección del cuestionario.

Se pueden calcular cinco subescalas a partir del siguiente sistema:

\begin{tabular}{|c|c|}
\hline \multirow{2}{*}{$\begin{array}{l}\text { Información y conocimientos sobre } \\
\text { VIH }\end{array}$} & Sumar ítems $1,2,3,4,5,6,7,8,9,10,11,12$ \\
\hline & Las puntuaciones deben oscilar entre 0 y 24 \\
\hline \multirow{2}{*}{$\begin{array}{l}\text { Autoeficacia y actitudes hacia el uso } \\
\text { del preservativo }\end{array}$} & Sumar ítems 13, 14, 15, 16, 17, 18, 19, 20, 21 \\
\hline & Las puntuaciones deben oscilar entre 9 y 54 \\
\hline \multirow[t]{2}{*}{ Intención de uso del preservativo } & Sumar ítems 27, 28, 29, 30, 31, 32 \\
\hline & Las puntuaciones deben oscilar entre 0 y 18 \\
\hline \multirow[t]{2}{*}{ Conducta sexual segura } & Sumar ítems 33, 34, 35, 36, 37, 38 \\
\hline & Las puntuaciones deben oscilar entre 0 y 18 \\
\hline \multirow{2}{*}{$\begin{array}{l}\text { Solidaridad y empatía hacia las } \\
\text { personas afectadas por VIH }\end{array}$} & Sumar ítems 40, 41, 42, 43, 44 \\
\hline & Las puntuaciones deben oscilar entre 0 y 206 \\
\hline
\end{tabular}

Otra información

El cuestionario ofrece ítems complementarios que evalúan otros factores relevantes en la prevención del VIH:

- Ítem 22 y 23: vulnerabilidad percibida y temor percibido a la infección por VIH.

- Ítem 24: gravedad percibida a la infección por VIH. 
Validation of the Aids Prevention Questionnaire

- $\quad$ Ítem 25: confianza en el uso del preservativo.

- Ítem 26: norma percibida.

- Ítem 39: realización de las pruebas de detección de VIH. 
Appendix 2. Answer sheet and correction criteria of the AIDS Prevention Questionnaire in English language.

1. Have you ever received information about any of the following topics?

\begin{tabular}{|l|c|c|}
\hline & Yes & No \\
\hline 1.1. Sexuality & 1 & 0 \\
\hline 1.2. Methods of contraception & 1 & 0 \\
\hline 1.3. Sexually transmitted infections & 1 & 0 \\
\hline 1.4. HIV-AIDS & 1 & 0 \\
\hline
\end{tabular}

2. How would you rate your level of knowledge about HIV-AIDS prevention?

\begin{tabular}{|c|c|c|c|}
\hline Bad & Regular & Good & Very good \\
\hline 0 & 1 & 2 & 3 \\
\hline
\end{tabular}

3. How did you get information about HIV-AIDS?

\begin{tabular}{|l|c|c|}
\hline & Yes & No \\
\hline 3.1. From parents & 1 & 0 \\
\hline 3.2. From friends & 1 & 0 \\
\hline 3.3. From teachers & 1 & 0 \\
\hline 3.4. From talks and workshops on prevention & 1 & 0 \\
\hline 3.5. From information campaigns & 1 & 0 \\
\hline
\end{tabular}

4. If the condom is not used, by which of the following sexual practices can HIV be transmitted?

\begin{tabular}{|l|c|c|}
\hline & Yes & No \\
\hline 4.1. Mutual masturbation & 0 & 1 \\
\hline 4.2. Oral sex & 1 & 0 \\
\hline 4.3. Vaginal sex & 1 & 0 \\
\hline 4.4. Anal sex & 1 & 0 \\
\hline
\end{tabular}

\begin{tabular}{|l|c|c|}
\cline { 2 - 3 } \multicolumn{1}{l|}{} & Yes & No \\
\hline 5. Can HIV be transmitted if only oral sex is practiced? & 1 & 0 \\
\hline $\begin{array}{l}\text { 6. Is the pulling out method, that is, when the penis is removed before ejaculation, } \\
\text { an effective method to prevent the transmission of HIV? }\end{array}$ & 0 & 1 \\
\hline 7. At first sight, Can I identify if somebody is HIV-positive? & & 0 \\
\hline
\end{tabular}




\begin{tabular}{|l|c|c|}
\hline $\begin{array}{l}\text { 8. Can a HIV-positive person transmit the virus if he/she does not show } \\
\text { symptoms? }\end{array}$ & 1 & 0 \\
\hline 9. Do most people living with HIV show symptoms of being sick right away? & 0 & 1 \\
\hline 10. Do you know where you can be tested for HIV? & 1 & 0 \\
\hline $\begin{array}{l}\text { 11. HIV-positive result implies to develop AIDS later? } \\
\text { 12. Do you know the existence of a window period for checking the HIV } \\
\text { antibody test? }\end{array}$ & 0 & 1 \\
\hline
\end{tabular}

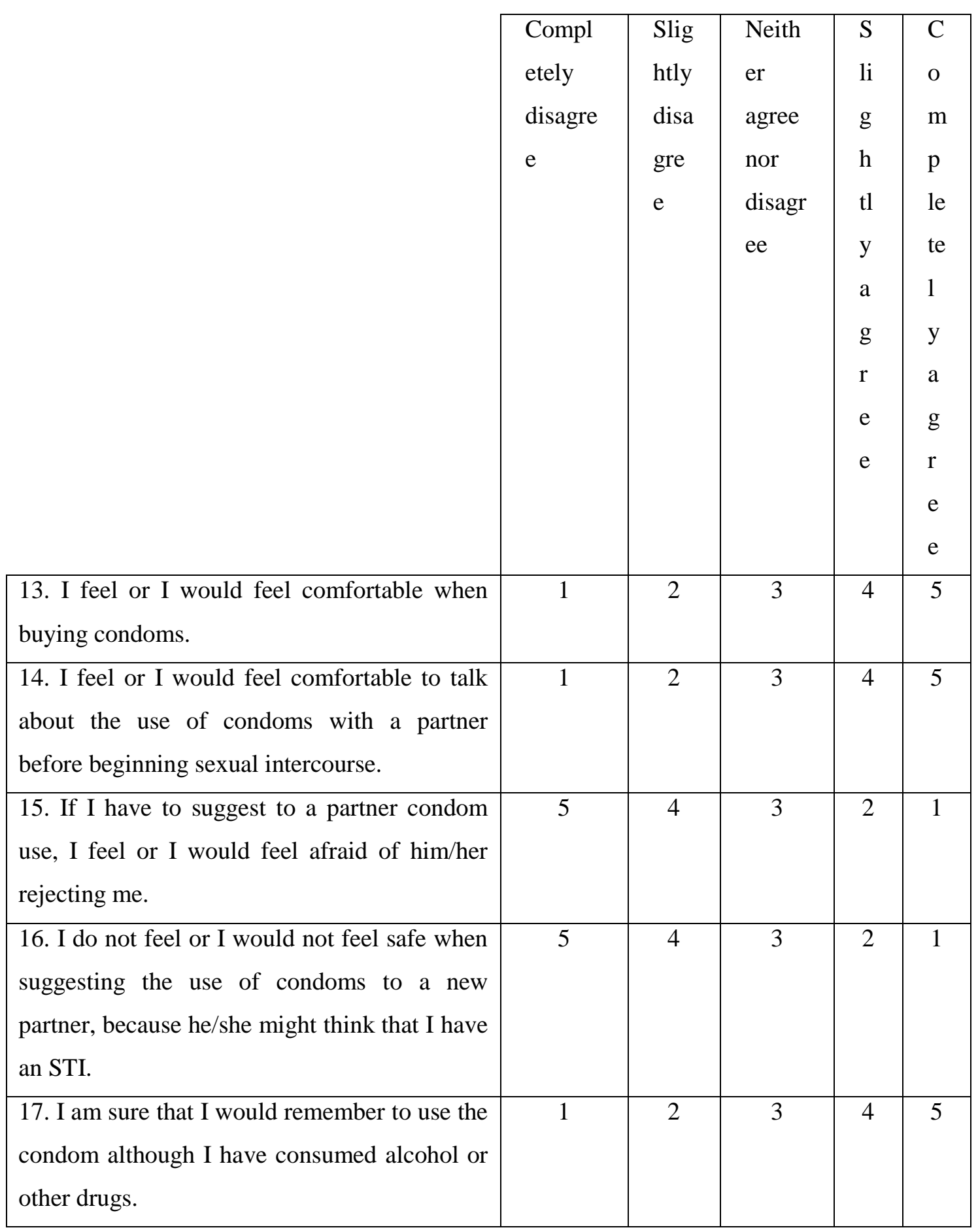




\begin{tabular}{|l|l|l|l|l|l|}
\hline $\begin{array}{l}\text { 18. I feel or I would feel uncomfortable when } \\
\text { I put the condom on or put it on my partner. }\end{array}$ & 5 & 4 & 3 & 2 & 1 \\
\hline $\begin{array}{l}\text { 19. I am sure that I could stop to put on the } \\
\text { condom or put it on my partner regardless of } \\
\text { the moment of greater excitement. }\end{array}$ & 1 & 2 & 3 & 4 & 5 \\
\hline $\begin{array}{l}\text { 20. I know how to use condoms in my sexual } \\
\text { relationships. }\end{array}$ & 1 & 2 & 3 & 4 & 5 \\
\hline $\begin{array}{l}\text { 21. I know in what aspects I have to pay } \\
\text { attention when I use condoms. }\end{array}$ & 1 & 2 & 3 & 4 & 5 \\
\hline
\end{tabular}

22. Indicate from 0 to 100 the probability or risk you perceive of being able to contract HIV:

23. Indicate from 0 to 100 the fear that you feel towards the possibility of contract HIV:

24. The HIV-AIDS is a disease:

\begin{tabular}{|c|c|c|c|}
\hline Mild & Moderate & Serious & Fatal \\
\hline 0 & 1 & 2 & 3 \\
\hline
\end{tabular}

25. Do you consider condoms as a reliable method for HIV sexual prevention?

\begin{tabular}{|c|c|c|c|}
\hline None & Somewhat & Quite & Much \\
\hline 0 & 1 & 2 & 3 \\
\hline
\end{tabular}

\begin{tabular}{|l|c|c|}
\cline { 2 - 3 } \multicolumn{1}{c|}{ 26. Is condom use viewed favorably by most of the important people to you? } & 1 & 0 \\
\hline
\end{tabular}

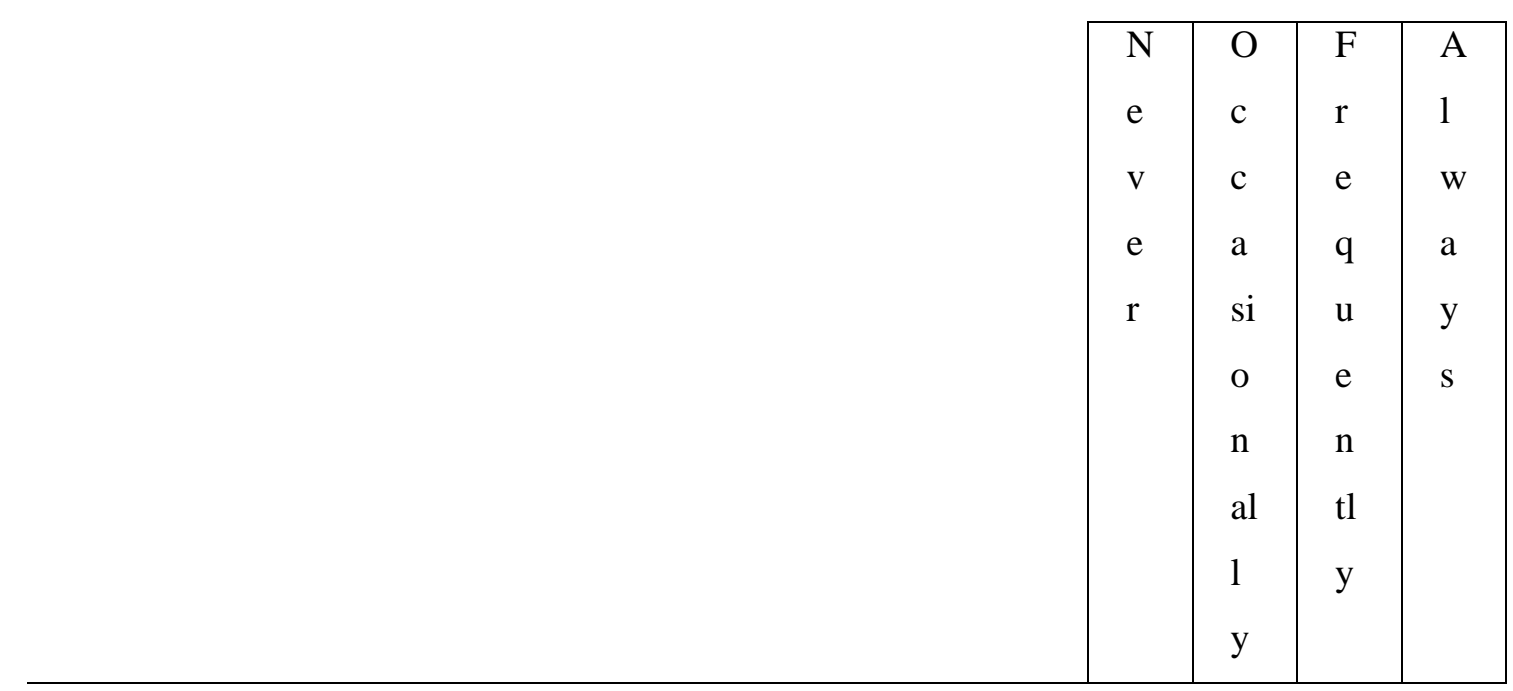




\begin{tabular}{|l|l|l|l|l|}
\hline $\begin{array}{l}\text { 27. How often do you intend to use condoms in the coming } \\
\text { vaginal intercourse? }\end{array}$ & 0 & 2 & 3 \\
\hline $\begin{array}{l}\text { 28. How often do you intend to use condoms in the coming oral } \\
\text { sex practice? }\end{array}$ & 0 & 1 & 2 & 3 \\
\hline $\begin{array}{l}\text { 29. How often do you intend to use condoms in the coming anal } \\
\text { intercourse? }\end{array}$ & 0 & 1 & 2 & 3 \\
\hline $\begin{array}{l}\text { 30. How often do you intend to use condoms in the coming } \\
\text { relationships with a steady partner? }\end{array}$ & 0 & 1 & 2 & 3 \\
\hline $\begin{array}{l}\text { 31. How often do you intend to use condoms in the coming } \\
\text { relationships with a sporadic partner? }\end{array}$ & 0 & 1 & 2 & 3 \\
\hline $\begin{array}{l}\text { 32. How often do you intend to use condoms in the coming } \\
\text { relationships under the effects of alcohol or drugs consumption? }\end{array}$ & 0 & 1 & 2 & 3 \\
\hline $\begin{array}{l}33 . \text { How often do you use condoms in vaginal intercourse? } \\
\text { 34. How often do you use condoms in oral sex? }\end{array}$ & 0 & 1 & 2 & 3 \\
\hline $\begin{array}{l}\text { 35. How often do you use condoms in anal intercourse? } \\
\text { 36. How often do you use condoms in relationships with a steady } \\
\text { partner? }\end{array}$ & 0 & 1 & 2 & 3 \\
\hline $\begin{array}{l}\text { 37. How often do you use condoms in relationships with sporadic } \\
\text { partners? }\end{array}$ & 0 & 1 & 2 & 3 \\
\hline $\begin{array}{l}38 . \text { How often do you use a condom under the effects of alcohol } \\
\text { or drugs consumption? }\end{array}$ & 0 & 1 & 2 & 3 \\
\hline
\end{tabular}

39. Have you ever got an HIV antibody test?

\begin{tabular}{|c|c|}
\hline Yes & No \\
\hline 1 & 0 \\
\hline
\end{tabular}

40. On a scale from 0 to 100 , how much do you think an HIV-positive person suffers socially and physically?

41. On a scale from 0 to 100 , how much do you think society should be more understanding and supportive of HIV-positive people?

\begin{tabular}{|l|c|c|}
\cline { 2 - 3 } \multicolumn{1}{l|}{} & Yes & No \\
\hline $\begin{array}{l}\text { 42. Would you stop meeting with a friend if you found out that he/she is HIV- } \\
\text { positive? }\end{array}$ & 0 & 1 \\
\hline 43. Would you take care for a HIV-positive friend? & 1 & 0 \\
\hline 44. Would you avoid meeting HIV-positive someone? & 0 & 1 \\
\hline
\end{tabular}


Scoring

Five subscales scores can be calculated from following system:

\begin{tabular}{|c|c|}
\hline \multirow[t]{2}{*}{ Knowledge about HIV (K-HIV) } & Add items $1,2,3,4,5,6,7,8,9,10,11,12$ \\
\hline & Scores should range between 0 and 24 \\
\hline \multirow[t]{2}{*}{ Self-efficacy and attitudes (SEA) } & Add items $13,14,15,16,17,18,19,20,21$ \\
\hline & Scores should range between 9 and 54 \\
\hline \multirow[t]{2}{*}{ Condom Use Intentions (CUSEI) } & Add items 27, 28, 29, 30, 31, 32 \\
\hline & Scores should range between 0 and 18 \\
\hline \multirow[t]{2}{*}{ Safe sexual behavior (SAS-B) } & Add items $33,34,35,36,37,38$ \\
\hline & Scores should range between 0 and 18 \\
\hline \multirow{2}{*}{$\begin{array}{l}\text { Stigma and discrimination towards } \\
\text { people living with HIV (SD-HIV) }\end{array}$} & Add items $40,41,42,43,44$ \\
\hline & Scores should range between 0 and 206 \\
\hline
\end{tabular}

Other information

The questionnaire offers complementary items that measure other factors relevant to HIV prevention:

- Item 22 and 23: perceived susceptibility and perceived threat of HIV

- Item 24: perceived seriousness of HIV.

- Item 25: trust on condom use.

- Item 26: perceived norm.

- Item 39: HIV testing behavior. 